\title{
Bring some colour to your package: Freshness indicators based on anthocyanin extracts
}

\author{
Raquel Becerril ${ }^{\mathrm{a}}$, Cristina Nerín ${ }^{\mathrm{a}}$, Filomena Silva ${ }^{\mathrm{b}, \mathrm{c}, *}$ \\ ${ }^{a}$ I3A-Aragón Institute of Engineering Research, University of Zaragoza, Calle María de Luna 3, 50018, Zaragoza, Spain \\ ${ }^{\mathrm{b}}$ ARAID-Agencia Aragonesa para la Investigación y el Desarollo, Av. de Ranillas 1-D, planta $2^{a}$, oficina B, 50018, Zaragoza, Spain \\ ${ }^{\text {c }}$ Faculty of Veterinary Medicine, University of Zaragoza, Calle de Miguel Servet 177, 50013, Zaragoza, Spain
}

\section{A R T I C L E I N F O}

\section{Keywords:}

Freshness sensor

Intelligent packaging

Anthocyanin

$\mathrm{pH}$ indicator

\begin{abstract}
A B S T R A C T
Background: Nowadays, consumers are more aware about what they eat and how it is packaged. Food quality is of paramount importance and consumers are eager to be constantly updated about the perishability and shelf-life of the food products they buy. This gave rise to intelligent packaging (IP) materials and devices that can communicate with all people throughout the entire food route. One of the main colour-based IP systems is based on the use of anthocyanin (ATH)-based natural dyes by exploiting their $\mathrm{pH}$-dependent colour changes that can be easily readable by the naked eye.

Scope and approach: This review focuses on recent studies regarding ATH-based sensor packaging materials development for IP applications, offering valuable insights regarding the main factors that affect the efficacy of the developed IP, such as the material where the ATH is anchored, ATH type and concentration, the ingredients used in the formulation of the sensor and the storage conditions of the food product. Additionally, the last ATHbased IP developed are also summed and discussed in detail to identify the major bottlenecks that need to be overcome for accelerating the commercial application of ATH-based sensors in IP.

Key findings and conclusions: Although ATH-based indicators are able to correctly indicate food shelf-life in several products at a laboratory scale, their industrial production is still impaired by the production methods used for this type of sensors. Furthermore, ATHs are labile compounds that require stabilization in the packaging material to yield stable, standardized and durable IP materials.
\end{abstract}

\section{Introduction}

In the last decades, consumers became more and more aware about what they eat. Besides requesting minimally processed and highly nutritional foods, they also demand chemically and microbiologically safer foods with increased shelf-life. All these consumers' needs in conjunction with food globalization, have driven the food packaging industry for the development of new types of packaging materials that are not only able to contain the food and protect it from the environment, but are also able to increase product's shelf-life (active packaging) and communicate with the consumer in terms of the safety and freshness of the product (intelligent packaging, IP) (Borzi, Torrieri, Wrona, \& Nerín, 2019; Poyatos-Racionero, Ros-Lis, Vivancos, \& Martínez-Máñez, 2018; Wu, Wang, Hu, \& Nerín, 2018).

In addition, food packaging innovations have been driven towards more environmental-friendly solutions by preferring natural substances over synthetic ones, both in the packaging materials (Han, Ruiz-Garcia, Qian, \& Yang, 2018) as well as in the compounds that are incorporated in the package to make it an active and/or intelligent package. For this purpose, a great amount of biopolymers with improved properties regarding barrier or mechanical features have been created from lipids, polysaccharides and/or proteins and applied to different types of food in last years (Gómez-Estaca, Gavara, Catalá, \& Hernández-Muñoz, 2016; Mohamed, El-Sakhawy, \& El-Sakhawy, 2020; Nerin, Becerril, Manso, \& Silva, 2016). Regarding the use of natural compounds as active agents, there is a vast amount of research describing the use of compounds derived from plants for the development of antioxidant and/or antimicrobial food packaging materials (Gherardi, Becerril, Nerin, \& Bosetti, 2016; Silva, Domingues, \& Nerín, 2018; Wrona et al., 2019).

On the other hand, when focusing on intelligent food packaging materials, the preferred natural compounds include those that are capable of responding to changes in either the packaged food or its

\footnotetext{
* Corresponding author. ARAID-Agencia Aragonesa para la Investigación y el Desarollo, Av. de Ranillas 1-D, planta 2a , oficina B, 50018, Zaragoza, Spain.

E-mail addresses: raquel@unizar.com (R. Becerril), cnerin@unizar.es (C. Nerín), filomena@unizar.es (F. Silva).
} 
environment inside the package such as temperature, $\mathrm{pH}$, microbial growth, volatile substances, etc., and which provide readily visible and comprehensive information to the user. The singularity of intelligent packaging is its ability to communicate with the food product, without interacting with it (Müller \& Schmid, 2019). As long as the food is packaged, this communication is constant and uninterrupted throughout all the supply chain, from the producer to the retailer, and finally to consumers: as the package and the food product move together throughout the entire chain, the package is the ideal vehicle to communicate any alteration in the conditions of the packaged food product (Yam, Takhistov, \& Miltz, 2005). One of the main food attributes that retailers and consumers are most worried about is freshness, as this is the main indicator that ensures both food quality and food safety.

\section{Freshness indicators}

Direct freshness indicators have emerged as a reliable tool to guarantee the safety and quality of the packaged food and to reduce food waste. Freshness indicators have been designed to monitor changes in quality or freshness of packaged food, such as microbial growth or the generation of undesirable substances, and transmit this information to the costumer (Fang, Zhao, Warner, \& Johnson, 2017; Kuswandi, 2017; Müller \& Schmid, 2019; Poyatos-Racionero et al., 2018). Data provided can be used to determine the shelf-life of the product together with the "use-by-date" or serve to optimize storage and distribution conditions (Kuswandi, 2017; Vanderroost, Ragaert, Devlieghere, \& De Meulenaer, 2014). The mode of action of a freshness indicator is based on the detection of qualitative or quantitative changes in the concentration of one or more substances inside the packaging that are related to food deterioration, and a subsequent transduction of these changes to perceptible signals that can be visually detected by consumers. In the case of colorimetric indicators (Fig. 1) for example, changes in the concentration of compounds such as glucose, volatile nitrogen compounds, biogenic amines, carbon dioxide or sulphide compounds are transduced into colour changes that can be notice by consumers.

A freshness indicator should fulfill several requirements for a successful development and implementation in the food industry that includes: (i) a suitable performance that allows a sensitive and fast monitoring of changes in the selected substances and a good correlation between the detected changes and the quality of the food product; (ii) an easy implementation in the food industry driven by low prices and the need of simple technology for their inclusion in the packaging material and; (iii) a simple reading and interpretation by consumers, without the need to use any specific device. This last requirement is broadly fulfilled by colorimetric indicators, being this the main reason of the high progress done in this type of devices, some of them already launched into the market as Freshcode $₫$, Freshtag $₫$ or Ripesense ${ }^{\circledR}$.

A freshness indicator based on $\mathrm{pH}$ sensitive dyes is one of the strategies used to detect the deterioration of several types of foods such as fish, meat and dairy products (Alizadeh-Sani, Mohammadian, Rhim, \& Jafari, 2020). When a certain food begins its deterioration process, a pH change occurs; this change can be monitored by a pH indicator that is embedded in a solid support or on the packaging material itself
(Balbinot-Alfaro et al., 2019). These changes in the $\mathrm{pH}$ indicator usually translate into a colour change, meaning that most $\mathrm{pH}$-based freshness indicators are colorimetric sensors. This approach has been widely used for raw fish or meat products as they increase their $\mathrm{pH}$ during the decay process due to the growth of spoilage microorganisms that yields nitrogen compounds.

Although most freshness indicators based on $\mathrm{pH}$ changes used synthetic dyes, in recent years, research has been conducted to substitute these synthetic dyes by naturally occurring $\mathrm{pH}$ indicators, especially anthocyanin-rich extracts obtained from plants. Besides their natural origin, anthocyanins (ATH) present several advantages as they are easy to obtain, widely distributed in nature and cheap, making them a good alternative to synthetic dyes. Additionally, anthocyanins also circumvent the toxicity issues related with the use of synthetic dyes as anthocyanin toxicity has not been shown in human intervention studies and according to the last re-evaluation of the Scientific Panel on Food Additives and Nutrient Sources Added to Food from the European Food Safety Authority, anthocyanins (mostly grape-skin and black currant extracts) were considered unlikely to be of safety concern (EFSA, 2013; Wallace \& Giusti, 2015).

The development of $\mathrm{pH}$-sensitive smart packaging based on anthocyanins and other natural food colourants have been recently reviewed (Alizadeh-Sani et al., 2020; Bhargava, Sharanagat, Mor, \& Kumar, 2020; Kalpana, Priyadarshini, Maria Leena, Moses, \& Anandharamakrishnan, 2019; Roy \& Rhim, 2020). Although most of these reviews summarize the main characteristics of anthocyanin extracts and their incorporation in biopolymers for the development of novel smart packaging, they are not focused on the mechanistics behind the development of anthocyanin-based smart food packaging materials such as the interactions between the anthocyanin extract and the polymeric matrix, the interaction of the ATH-based indicator with the food product and the issues concerning ATH migration and indicator stability, and colour assessment and its relation to food spoilage.

\section{Anthocyanins}

Anthocyanins are the most important pigments of vascular plants that provide many of the blue, red, orange, pink and violet colours observed in flowers, berries, leaves, stems and roots of many plants (Castañeda-Ovando, Pacheco-Hernández, Páez-Hernández, Rodríguez, \& Galán-Vidal, 2009). Chemically, these water soluble pigments belong to the widespread class of phenolic compounds collectively named flavonoids whose structure is based on the flavylium cation. The structure of anthocyanins consists on a core called anthocyanidin, which is composed of two aromatic rings linked to an oxygenated heterocycle, that can be bonded to different sugar moieties (Smeriglio, Barreca, Bellocco, \& Trombetta, 2016) (Fig. S1). The flavylium ion is the chromophore moiety of the anthocyanin and is responsible for the high instability and susceptibility to degradation of these coloured substances (Smeriglio et al., 2016).

To date, 23 different anthocyaninidins have been described with variations in the number and degree of methylation of hydroxyl groups in one of the rings. In vascular plants, the six most common anthocyanins are pelargodinin, cyanidin, delphinidin, malvidin, peodinin and

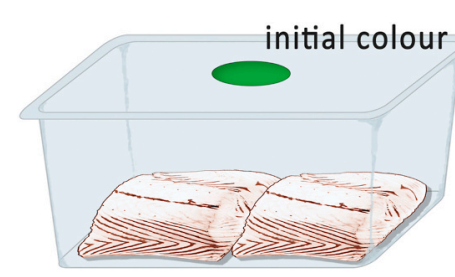

Fresh

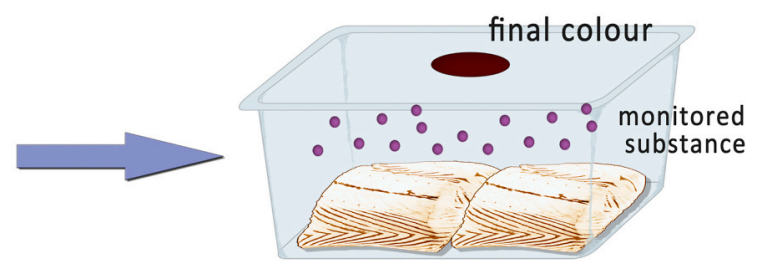

Spoiled

Fig. 1. Schematic operating mode of a colorimetric freshness indicator. 
petudinin (Clifford, 2000) (Fig. S1), being cyanidins (which contain two hydroxyl groups) the most widely distributed species. Regarding anthocyanins, there are reports of more than 500 different types (Castañeda-Ovando et al., 2009). The main differences between them are the number of hydroxylated groups, the nature and the number of bonded sugars and the number and position of the aliphatic or aromatic carboxylates bonded to the sugar moieties (Castañeda-Ovando et al., 2009). These differences imply consequent variations in stability, and hues (Rodriguez-Amaya, 2019). The relative abundance of anthocyanins varies greatly according to the plant species, time of harvest or growing conditions, with light being one of the most important environmental factors that affects ATH biosynthesis (Gu, Wang, Hu, \& Hao, 2019; Tsuda, 2012).

The attractive colours, high water solubility and biological properties of ATH together with their natural origin and low toxicity have attracted a great interest by researchers, industry and consumers towards their application in the food industry and in food products. Nowadays, ATH are widely used as food colorants in some types of processed foods and beverages replacing older pigment substances of synthetic origin. Furthermore, ATH can be used as antioxidants in food products by adding them directly into the food or by their incorporation into the packaging material (Ahmad, Gokulakrishnan, Giriprasad, \& Yatoo, 2015; Lorenzo et al., 2018; Wang, Yong, et al., 2019). In fact, the use of ATH as food additives is reinforced by their proven benefits to human health that include anti-inflammatory, antioxidant, antiobesity, antiangiogenesis, anticancer, antidiabetes, antimicrobial, neuroprotective and immunomodulatives properties (Li, Wu, Fu, \& Reddivari, 2019).

As mentioned above, anthocyanins possess low stability due to the presence of the flavylium ion and its peculiar electron distribution (Smeriglio et al., 2016). This instability, besides the undesirable interactions with food products, limits the use of ATH in the food industry. The ATH chemical structure is critical to its stability, as it has been proved that the increase of methoxyl groups enhances stability, whereas the increase of hydroxyl groups yields the opposite effect (Tarone, Cazarin, \& Marostica Junior, 2020). Additionally, the anthocyanin glycosyl acylation has demonstrated to strengthen the in vitro and in vivo chemical stability of ATH (Zhao et al., 2017). Hence, a correct selection of the plant raw material is essential to obtain extracts with high content of chemically stable anthocyanins. Nowadays, black carrot, red cabbage or purple sweet potato are used extensively as sources of anthocyanins because of their high contents of stable acetylated anthocyanins. Anthocyanin stability is improved in nature by interaction with other anthocyanins, metallic ions, phenolic compounds and other non-phenolic substances like pectin polysaccharides as happen (Castañeda-Ovando et al., 2009; Cavalcanti, Santos, \& Meireles, 2011; Cortez, Luna-Vital, Margulis, \& Gonzalez de Mejia, 2017). These associations not only enhance the stability but can also lead to changes or increments in colour intensity. This phenomenon, which is called copigmentation is the main responsible for the final colours that plants show in nature. Interactions might also be used in the food industry to increase the stability and improve the colour characteristics of the extracts (Chung, Rojanasasithara, Mutilangi, \& McClements, 2015; Cortez et al., 2017; Koh, Xu, \& Wicker, 2020; Xu et al., 2019).

The use of proper ATH extraction methods is also essential to avoid high ATH degradation rates and to obtain large yields. The classical procedures are based in the extraction by a solvent, generally of polar type such as methanol, ethanol, acetone or water, acidified with a vast array of both organic and inorganic acids. However, efforts have been made to use other more advantageous modern techniques to reduce the amount of solvent used, improve the kinetics of the extraction, diminish the need for purification and concentration steps or increase the extraction yield (Silva, Costa, Calhau, Morais, \& Pintado, 2017). Among them, ultrasound-assisted, microwave-assisted and pressurized liquid extractions have demonstrated great potential for ATH extraction. Notwithstanding, these techniques have limited effectiveness and should be applied at low temperatures to avoid ATH degradation (Silva et al., 2017).

Due to their ionic structure, ATHs in solution can be found as different chemical species depending on the $\mathrm{pH}$ (Fig. 2). This singularity has also important consequences in ATH stability and colour. Regarding stability, it is widely accepted that the predominant species at low $\mathrm{pH}$ display much higher stability than the more common species at higher pH (Cavalcanti et al., 2011; Khoo, Azlan, Tang, \& Lim, 2017). Concerning colour, the different hues observed for the different species make them behave as natural occurring $\mathrm{pH}$ indicators. It is known that ATH usually displays red colours at low $\mathrm{pH}$, whereas at higher $\mathrm{pH}$, the colour spectra changes to purple and blue colours (Cavalcanti et al., 2011). As mentioned before, this particular feature of ATHs has been the one most exploited in the development of freshness indicator based on $\mathrm{pH}$ indicators.

\section{Freshness indicators based on anthocyanins extracts}

In the last three years, the $\mathrm{pH}$-dependent colour change properties of anthocyanins have attracted attention for their use as colour indicators in food packaging applications. The development of fully functional anthocyanin-based freshness indicators is a very challenging process, where ATH extract and the polymer used as substrate play a decisive role. In order for it to work correctly, the ATH extract should be compatible with the polymer and able to respond to the freshness alterations suffered by the food product during its storage and distribution. Additionally, as these indicators are based on colour changes, colour alterations must be unequivocal and easily readable by the consumers/retailers and should always be related to a quality/shelf-life changes in the packaged food product. Other properties of ATH-based indicator as water resistance or stability are also crucial for a successful performance.

\subsection{Anthocyanin extracts}

The selection of the plant used as source of ATH is essential for the development of an ATH-based indicator, since it will determine the type of predominant ATH. As explained in the previous section, the type of ATH restrains the stability of the extract and produce hue variations. As can be seen in Fig. 3, the extracts obtained from different plants exhibit different hue variations at different $\mathrm{pH}$ which could affect the use of the ATH-based indicator.

The most commonly used plants for this purpose are red cabbage and purple sweet potato, accounting for more than $35 \%$ of all studies (Table S1), due to their high contents of cyanidins and peonidins in its monoacylated and diacetylated forms. These ATHs possess improved thermal- and photostability properties and exhibit a wider $\mathrm{pH}$ dependent colour spectrum when compared to the non-acylated anthocyanins (Li, Wu, et al., 2019; Strauch et al., 2019). Traditional sources of ATH such as blackberries and grapes are also being used as well as other more uncommon sources such as black soybean seed coat extracts (Wang, Xia et al., 2019), purple and black eggplant peels (Yong, Wang, Zhang, et al., 2019) or jambolan fruits (Merz et al., 2020). Another very interesting approach is the use of residues from juice processing as the primary source of ATH, such as the ones obtained from mulberry, blueberry, blackberry and chokeberry (Andretta, Luchese, Tessaro, \& Spada, 2019; Halász \& Csóka, 2018; Kurek et al., 2018; Luchese, Abdalla, Spada, \& Tessaro, 2018; Luchese, Sperotto, Spada, \& Tessaro, 2017; Zeng et al., 2019). Additionally, it was found that the use of blackberry processing residue (pomace) could reduce the degradation of ATH and improve the yield and colour quality (Kurek et al., 2018).

The concentration of ATH extract in the ATH-based indicator is an essential factor that should be adjusted for a correct functioning of the indicator. It has been demonstrated that excessively low concentrations of ATH produce less distinguishable colour changes (Ge et al., 2019; Kurek et al., 2018; Merz et al., 2020; Prietto et al., 2018; Zhang, Huang, 
<smiles>[R8]c1cc(-c2[o+]c3cc(O)cc(O)c3cc2O[GeH]([Z10])[O-])cc([R8])c1O</smiles>

Flavylium cation (red color)

pH 1<smiles>[R8]c1cc(-c2oc3cc(=O)cc(O)c-3cc2OC(C)(C)C)cc([R8])c1O</smiles>

Quinoidal base (blue color)

$\mathrm{pH} 7$

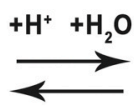

pH 4.5<smiles>[R8]c1cc(C(=O)/C(=C\c2c(O)cc(O)cc2O)OC(C)(C)C)cc([R8])c1O</smiles>

Chalcone (colorless)

$\mathrm{pH} 4.5$

Fig. 2. Anthocyanin chemical species depending on the $\mathrm{pH}$.

\section{$\begin{array}{lllllllllll}\text { pH } 2 & \text { pH } 3 & \text { pH } 4 & \text { pH } 5 & \text { pH6 } & \text { pH 7 } & \text { pH } 8 & \text { pH } 9 & \text { pH } 10 & \text { pH } 11 & \text { pH } 12\end{array}$}

A
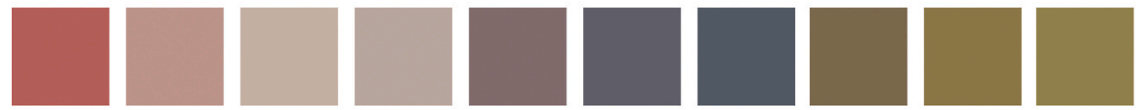

B
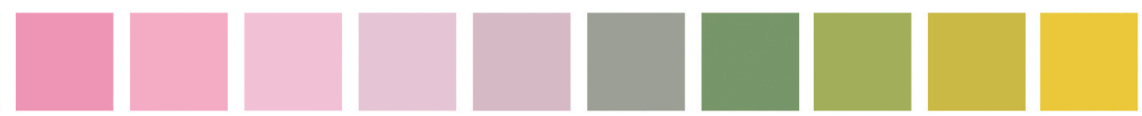

Fig. 3. Colour variations of (a) roselle and (b) purple sweet potato extract at different pH. Adapted from Jiang et al. (2020) and Zhai et al. (2017).
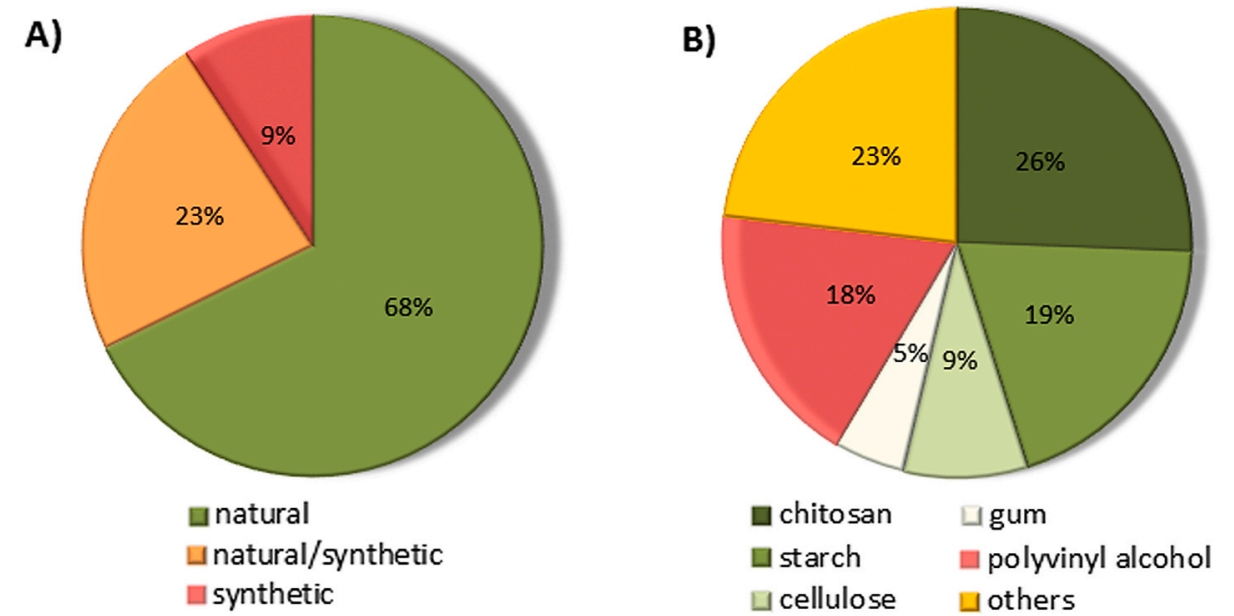

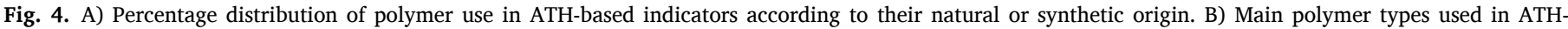
based indicators. 
Yan, Hu, \& Ren, 2020) whereas too high concentrations have lower pronounced variations, which can be attributed to the interference caused by the colour of anthocyanin itself (Pourjavaher, Almasi, Meshkini, Pirsa, \& Parandi, 2017; Qin et al., 2019; Zhang et al., 2020). Because the concentration of ATH used for the development of the intelligent packaging materials is generally given as entire plant extract not as ATH content, it is difficult to compare between different works and establish concentrations ranges that could be more effective. Besides, concentrations of ATH extracts are generally expressed in terms of film forming solution or coating. It would be more convenient to give the data of ATH content per film surface unit for a better comparison between the different final indicator materials.

\subsection{Polymer substrate}

Another critical component of a freshness indicator based on $\mathrm{pH}$ dyes is the substrate used to anchor the dye. On the same mind of the new trends for food packaging, most of the ATH-based indicators have been made from polymers of natural origin (Fig. 4a). The use of starch and chitosan stands out, although cellulose, gelatin or several gums, have also been employed for this purpose (Fig. 4b). Regarding polymers of synthetic origin, polyvinyl alcohol (PVA) alone or in combination was predominantly used in a percentage similar to starch (Fig. 5b). These water-based polymers have been the preferred ones, mostly due to the fact that the water solubility of anthocyanins facilitates their incorporation in these polymers.

It should be noted that the polymer matrix must comply with some basic requirements to be used in the development of ATH-based indicators. In particular, it should be stable at low $\mathrm{pH}$ to assure anthocyanin stability, almost colourless to avoid masking ATH colour, moisture sensitive to allow the correct mode of action of the ATH-based indicator, and possess adequate mechanical properties. Generally, to obtain materials with these properties, two or more different polymers are combined and different additives are added. Some works have combined polymers of natural origin and others have mixed those from natural origin with other water soluble synthetic polymers, especially PVA (Fig. 4 and Table S2). Novel substances such as bentonite nanoclays (Koosha \& Hamedi, 2019), montmorillonite (Kang et al., 2018), chitosan nanoparticles or chitin nanocrystals (Ge et al., 2019; Ma, Liang, Cao, \& Wang, 2018; Wu, Tsai, et al., 2020, 2019) (Table S2) have been added to improve mechanical, structural and barrier properties. It should be noted that many works use glycerol as plasticizer and linking agents such as boric acid, glutaraldehyde, polyphosphate or trimetaphosphate (Jiang et al., 2020; Kang et al., 2018; Mustafa et al., 2020; Pereira, de Arruda, \& Stefani, 2015; Vo, Dang, \& Chen, 2019; Zhang, Lu, \& Chen, 2014).

The final properties of the material and the mode of action of the ATH-based indicator not only depend on the innate characteristics of the material or the ATH extract, but also from the foreseeable interactions between both of them. These interactions play a fundamental role in the final structural, mechanical properties and water sensitivity of the material, determine the ATH retention ability and may cause changes in the $\mathrm{pH}$-dependent change of colour of ATH and in ATH retention in the material.
With respect to the alterations in the mechanical and structural properties of the polymers resulting from ATH addition, different results have been described depending on the combinations of polymers, ATH extracts and concentrations used. In some cases, no changes have been observed in polymer parameters such as tensile strength, elongation at break or water vapor permeability (Andretta et al., 2019; Chen \& Gu, 2013; Uranga, Etxabide, Guerrero, \& de la Caba, 2018; Yong, Wang, Zhang, et al., 2019). On the other hand, an improvement or decline in the properties of the material have been observed after the addition of the ATH extract (Andretta et al., 2019; Chi et al., 2020; Jiang et al., 2020; Kang et al., 2020; Koosha \& Hamedi, 2019; Liu et al., 2019; Luchese et al., 2018; Pourjavaher et al., 2017; Qin et al., 2019; Rawdkuen, Faseha, Benjakul, \& Kaewprachu, 2020; Vo et al., 2019; Wei, Cheng, Ho, Tsai, \& Mi, 2017; Wu et al., 2019, 2020; Yoshida, Maciel, Mendonça, \& Franco, 2014; Zeng et al., 2019; Zhai et al., 2017; Zhang et al., 2019; Zhang et al., 2020). Additionally, some authors have described that these polymer alterations depend on the concentration of ATH included (Ge et al., 2019; Ma et al., 2018; Ma \& Wang, 2016; Yong, Wang, Bai, et al., 2019; Yong, Wang, Zhang, et al., 2019; Zhang et al., 2020). However, although these changes in the polymer occur, they do not seem to play a critical factor in the development of ATH-based indicators, since indicator materials tend to be included as a label being a minor component of the package (Pereira et al., 2015).The effect of ATH-polymer interactions in the water sensitivity of the material, particularly in its swelling (water uptake) ability and its resistance in the presence of water, is an important issue considering that indicators based on $\mathrm{pH}$ changes are generally applied to foods with high water content. Higher swelling could interfere with the indicator colour response efficiency leading to a faster ATH release (Ebrahimi Tirtashi et al., 2019; Pourjavaher et al., 2017); while low resistance to water would limit the applicability of ATH-based indicators to foods with high water content such as meat or fish.

The addition of ATH into several polymer materials has revealed different effects in the water uptake and solubility of the material. Increasing water absorption and solubility rates after ATH addition have been explained by a less compact structure with weaker bonds between polymer components and by the high hydrophilicity of ATH (Andretta et al., 2019; Maftoonazad \& Ramaswamy, 2019; Pourjavaher et al., 2017; Rawdkuen et al., 2020; Zhang et al., 2020). On the other hand, the reduction of water intake and solubility due to ATH addition has been attributed to ATH acetylation, and intermolecular interactions between the polymer components and ATH that decrease the interaction between the polymer and water (Ebrahimi Tirtashi et al., 2019; Halász \& Csóka, 2018; Jiang et al., 2020; Moazami Goodarzi et al., 2020; Qin et al., 2019; Wang, Yong, et al., 2019; Wei et al., 2017). These variable results indicated that it is essential to evaluate the sensitivity to water of the intelligent material containing the ATH-based indicator to achieve a stable and efficient indicator in humid conditions.

As mentioned above, ATH affinity to water along with the swelling ability of some polymeric materials can lead to ATH migration from the anchoring substrate to the surface of the intelligent film due to the presence of water, thus affecting the correct performance of the indicator (Guo et al., 2020; Liang, Sun, Cao, Li, \& Wang, 2019). In fact, some migration phenomena can be observed in photographs of ATH-based

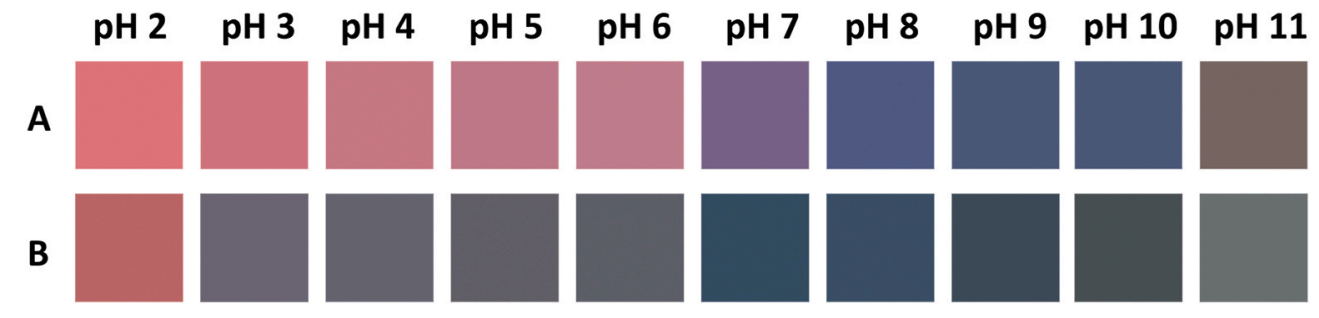

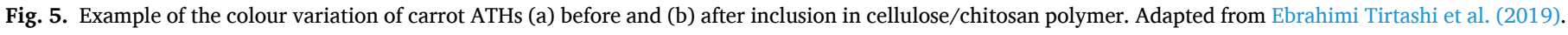
(For interpretation of the references to colour in this figure legend, the reader is referred to the web version of this article.) 
indicators that have been submerged in buffers with different $\mathrm{pH}$ (Chi et al., 2020; Choi, Lee, Lacroix, \& Han, 2017; Pereira et al., 2015; da Silva, Mastrantonio, Costa, \& de Morais, 2019; Vo et al., 2019; Wei et al., 2017). Although this poses a serious problem when developing this type of ATH-based intelligent packaging materials, only a few research works carried out released studies to evaluate this major bottleneck and propose solutions. For instance, Guo et al. (2020) observed migration of purple sweet potato ATH from fiber mats of zein and pullulan. This migration was initially high, due to the purple sweet potato located on or near the fiber surface, followed by a gradual increase in the release ascribed to the entrapped dye in the fiber. Migration was also detected in $\kappa$-carrageenan films containing Lycium ruthenicum Murr extract (Liu et al., 2019) and also in chitosan films containing black chokeberry (Halász \& Csóka, 2018). Other study also mentions the reduction in chroma values which was attributed to the migration of red cabbage extracts from PVA films after storage at $5{ }^{\circ} \mathrm{C}$ for 30 days (Maftoonazad \& Ramaswamy, 2019). To increase chemical interactions between ATH and polymeric matrix and, consequently, diminish ATH migration, low percentages of anionic polymers or other molecules have been added to film forming components. Using this approach, sodium carboxymethyl cellulose or pectin polymers have been added to films based on gum or chitosan, respectively, to achieve low release rates (Liang et al., 2019; Maciel, Yoshida, \& Franco, 2015). Regarding anionic molecules, negative charged oxidized nanocrystals and soy protein isolates have been added to konjac glucomannan films or gellan gum-based films, respectively, to obtain a reduction of ATH migration (Wu, Tsai, et al., 2020; Wu, Tsai, et al., 2020). Finally, chemical interactions between polymer matrices and anthocyanins can also result in some variation in the hue of ATH at different pHs and affect the colour variation efficiency of the ATH-based indicator (Pourjavaher et al., 2017). For instance, electrostatic interactions and hydrogen bonds observed between hydroxyl, amino and amide groups of chitosan, gelatin, pullulan, polyvinyl alcohol or cellulose (Ge et al., 2019; Guo et al., 2020; Liang et al., 2019; Merz et al., 2020; Pourjavaher et al., 2017; Silva-Pereira, Teixeira, Pereira-Júnior, \& Stefani, 2015; Wang et al., 2019a; Wu et al., 2019) could affect the electronic transitions responsible for the UV/Vis absorption bands and cause variations in the coloration of the ATH extracts. Fig. 5 shows an example of this phenomenon in black carrot extract included in a cellulose/chitosan polymer.

The most widely used method for the laboratory production of ATHbased intelligent films is casting. This method consists of pouring the polymeric film-forming solution containing ATH on small plates and subsequent drying. Despite of their simplicity, the casting methodology is not a common method used in the packaging industry since it is difficult to scale-up to produce large films and requires long drying times (De Moraes, Scheibe, Sereno, \& Laurindo, 2013). Another method that has been used in some works is the dip coating method (Ebrahimi Tirtashi et al., 2019; Moazami Goodarzi et al., 2020; Kang et al., 2018; Kuswandi, Asih, Pratoko, Kristiningrum, \& Moradi, 2020; Mohammadalinejhad, Almasi, \& Moradi, 2020; Moradi, Tajik, Almasi, Forough, \& Ezati, 2019; Pourjavaher et al., 2017). This procedure is based on the coating of a polymeric material with a layer of ATH by immersing it into an ATH solution that can contain other polymeric substances to facilitate ATH adherence to the film. The polymeric materials used are generally very porous and absorbent such as paper or bacterial cellulose, to ensure the absorption of enough ATH concentration for the correct performance of the intelligent packaging. For example, Kang et al. (2018) used a less porous material (polyethylene vinyl alcohol and montmorillonite) and had to employ three or five layers of ATH colorimetric coating to obtain good film coloration. Electrospinning have also been used to prepare fibrous films of zein, polycaprolactone-polyethylene oxide, PVA or pullulan-zein (Guo et al., 2020; Maftoonazad \& Ramaswamy, 2019; Prietto et al., 2018; da Silva et al., 2019) containing ATH. Fibrous mats have the advantage of possessing high porosity, small pore size and high surface-to-volume ratio that makes them very suitable for the loading of high amounts of active substances (Becerril, Nerín, \& Silva, 2020).

\subsection{Application of ATH-based indicators to food}

Many of the developed ATH-based indicators have been tested for monitoring the quality and freshness of selected types of packaged foods (Table 1). The food products tested display an increase or decrease on their $\mathrm{pH}$ during their shelf-life, with this $\mathrm{pH}$ change being related to ATH changes in colour. Besides, as mentioned before, they possess high water content, which is necessary to create a humid environment for the $\mathrm{pH}$ sensing of the ATH to occur. In particular, ATH-based indicators have been applied mainly to pork meat, fish, shrimp and milk (Table 1). Additionally, ATH-based sensors application to chicken meat and rutab fruit has also been described (Table 1). In the case of meat, fish and shrimp, ATH monitors $\mathrm{pH}$ increase resulting mainly from microbial growth and the subsequent production of alkaline compounds, mainly volatile nitrogen containing substances. The high volatility of these alkaline compounds allows the placement of the ATH-based $\mathrm{pH}$ indicator in the headspace of the food package, which means without direct contact between the food product and the ATH-based indicator. In the case of milk, ATH detects the reduction of $\mathrm{pH}$ that produces the growth of microorganisms, mainly acid lactic bacteria.

The application of ATH-based indicators on food packaging has demonstrated that these new intelligent materials change their colour along with the deterioration of the food product. However, their operation varies greatly between works, which can be considered reasonable taking into account the use of different ATH extracts, polymers and ATH concentrations. Some materials showed very distinguishable colour changes while others have colour variations more difficult to perceive by the naked eye. Some examples of ATH-based indicators applied to food products with colour changes that can be easily perceived by the consumers are shown in Table 2. It is important to point out that most research studies not only describe the relation between colour change and microbial spoilage but have also linked it to the expected shelf-life of the food product, which is the ultimate goal for a freshness indicator. In the case of pork, shrimp and fish, the authors have established that the end of the shelf-life of these products is attained when the concentration of volatile basic nitrogen substances (total volatile basic nitrogen value, TVBN) is higher than the limit established by current legislation and when the number of microorganism is higher than $7 \mathrm{log}$ CFU/g (Jiang et al., 2020; Kang et al., 2018; Qin et al., 2019; Zeng et al., 2019). In the case of milk, the end of shelf-life has been established according to the total acid content (TA) value. Milk with TA values higher than $20^{\circ} \mathrm{D}$ is not accepted by qualified judges while milk with values higher than $30^{\circ} \mathrm{D}$ is not accepted by common consumers (Ebrahimi Tirtashi et al., 2019; Kuswandi et al., 2020; Moazami Goodarzi et al., 2020).

As mentioned, ATH-based indicators applied to meat and products can be used without direct contact between the indicator and the food product. Taking advantage of this feature, the most used approach is the placement of ATH-based indicators in the inner side of the package without any contact with the food (Table 1) to only detect changes of $\mathrm{pH}$ caused by volatile substances released by the food during its storage and subsequent deterioration. Only some works have tested these intelligent materials directly on the surface of meat or fish products (Luchese et al., 2018; Vo et al., 2019; Wu, Tsai, et al., 2020) (Table 1); probably because it involves more disadvantages. In direct contact, the hydrophilic polymer indicators are exposed to higher water concentrations that could produce a high water uptake. Besides, the ATH extract could migrate to the food product easily as described by Luchese et al., 2018 after direct contact between chicken meat and ATH-based indicator containing blueberry residue. Along with that, food compounds could interfere with the correct functioning of the indicator or yield higher ATH degradation. In the headspace, the indicator is exposed to a more limited number of substances that can interact with ATH. Although indirect contact is the preferred mode of application of ATH-based sensors, there are some situations where direct contact is needed. For instance, in the use of ATH based indicators in milk, direct contact is required (Table 1), although the indicator is not continuously submerged in the milk but is only 
Table 1

ATH-based indicators applied to food products.

\begin{tabular}{|c|c|c|c|c|c|c|}
\hline $\begin{array}{l}\text { Tested } \\
\text { food }\end{array}$ & Source of ATH & Polymeric material & ATH extract concentration & $\begin{array}{l}\text { Type of } \\
\text { contact food- } \\
\text { indicator }\end{array}$ & $\begin{array}{l}\text { Storage } \\
\text { temperature }\end{array}$ & Reference \\
\hline \multirow[t]{8}{*}{ Milk } & \multirow[t]{3}{*}{ Red cabbage } & $\begin{array}{l}\text { PVA/chitosan film cross-linked with } \\
\text { tripolyphosphate }\end{array}$ & $\begin{array}{l}25 \% \text { total volume of the mixture } \\
\text { of hydrogels }\end{array}$ & Immersion & $25^{\circ} \mathrm{C}$ & Pereira et al. (2015) \\
\hline & & $\begin{array}{l}\text { PVA/starch film cross-linked with boric } \\
\text { acid }\end{array}$ & No data & Immersion & No data & Mustafa et al. (2020) \\
\hline & & Bacterial cellulose coated with ATH & Extract solution & Immersion & $25^{\circ} \mathrm{C}$ & Kuswandi et al. (2020) \\
\hline & Grape skins & Tara gum/cellulose nanocrystals film & $10 \mathrm{~g} / 100 \mathrm{~g}$ (tara gum basis) & Immersion & Room temperature & Ma and Wang (2016) \\
\hline & \multirow[t]{2}{*}{ Black carrot } & $\begin{array}{l}\text { Paper coated with a solution of chitosan/ } \\
\text { tetraethyl orthosilicate/ZnO } \\
\text { nanoparticles containing ATH extract }\end{array}$ & $\begin{array}{l}10.5 \mathrm{mg} \text { total ATH content } / 100 \\
\text { mL chitosan solution }\end{array}$ & Immersion & $20^{\circ} \mathrm{C}$ & $\begin{array}{l}\text { Ebrahimi Tirtashi et al. } \\
\text { (2019) }\end{array}$ \\
\hline & & $\begin{array}{l}\text { Paper coated with a solution of starch } \\
\text { containing ATH extract }\end{array}$ & $\begin{array}{l}10 \mathrm{mg} \text { total ATH content/100 } \\
\text { mL filmogenic solution }\end{array}$ & Immersion & $20^{\circ} \mathrm{C}$ & $\begin{array}{l}\text { Moazami Goodarzi et al. } \\
(2020)\end{array}$ \\
\hline & $\begin{array}{l}\text { Purple and } \\
\text { black eggplant } \\
\text { peel }\end{array}$ & Chitosan film & $\begin{array}{l}1,2 \text { and } 3 \%(w / w) \text { (chitosan } \\
\text { basis) }\end{array}$ & Immersion & $40^{\circ} \mathrm{C}$ & $\begin{array}{l}\text { Yong, Wang, Zhang, } \\
\text { et al. (2019) }\end{array}$ \\
\hline & $\begin{array}{l}\text { Lycium } \\
\text { ruthenicum } \\
\text { Murr fruit }\end{array}$ & $\kappa$-carrageenan film & $\begin{array}{l}1.5,2.5,3.5 \text { and } 4.5 \%(\mathrm{w} / \mathrm{w}) \\
\text { ( } \mathrm{k} \text {-carrageenan basis) }\end{array}$ & $\begin{array}{l}\text { Direct } \\
\text { contact }\end{array}$ & $25^{\circ} \mathrm{C}$ & Liu et al. (2019) \\
\hline \multirow[t]{9}{*}{ Pork } & Black carrot & Zein/pullulan fiber mat & $\begin{array}{l}20 \%(\mathrm{w} / \mathrm{w}) \text { (pullulan fibers } \\
\text { basis) }\end{array}$ & Headspace & $25^{\circ} \mathrm{C}$ & Guo et al. (2020) \\
\hline & $\begin{array}{l}\text { Purple sweet } \\
\text { potato }\end{array}$ & Agar/potato starch film & No data & $\begin{array}{l}\text { Direct } \\
\text { contact }\end{array}$ & $25^{\circ} \mathrm{C}$ & Choi et al. (2017) \\
\hline & Red cabbage & $\begin{array}{l}\text { Chitosan/PVA cross-linked with } \\
\text { tripolyphosphate }\end{array}$ & $\begin{array}{l}25 \mathrm{~mL} / 75 \mathrm{~mL} \text { filmogenic } \\
\text { solution }\end{array}$ & $\begin{array}{l}\text { Direct } \\
\text { contact }\end{array}$ & room temperature & (Vo et al., 2019) \\
\hline & Roselle calyx & Starch/PVA films & $\begin{array}{l}2.5 \%(\mathrm{w} / \mathrm{w}) \text { total mixed } \\
\text { hydrogels }\end{array}$ & Headspace & $25^{\circ} \mathrm{C}$ & (Zhang et al., 2019) \\
\hline & $\begin{array}{l}\text { Lycium } \\
\text { ruthenicum } \\
\text { Murr }\end{array}$ & Cassava starch film & 1,2 and $4 \%(w / w)$ (starch basis) & Headspace & $25^{\circ} \mathrm{C}$ & Qin et al. (2019) \\
\hline & \multirow[t]{2}{*}{ Grape skin } & $\begin{array}{l}\kappa \text {-carrageenan/hydroxypropylcellulose } \\
\text { film }\end{array}$ & $\begin{array}{l}6 \%(\mathrm{w} / \mathrm{w})(\kappa \text {-carrageenan and } \\
\text { hydroxypropylcellulose basis) }\end{array}$ & Headspace & $25^{\circ} \mathrm{C}$ & Chi et al. (2020) \\
\hline & & Cassava starch film & $\begin{array}{l}0.5 \%(\mathrm{w} / \mathrm{w}) \text { filmogenic } \\
\text { suspension }\end{array}$ & Headspace & $4{ }^{\circ} \mathrm{C}$ & $\begin{array}{l}\text { Golasz, Silva, and } \\
\text { Botelho Da Silva (2013) }\end{array}$ \\
\hline & $\begin{array}{l}\text { Prunus maackii } \\
\text { fruit }\end{array}$ & $\begin{array}{l}\kappa \text {-carrageenan/hydroxypropylcellulose } \\
\text { film }\end{array}$ & $\begin{array}{l}2,4,8 \text { and } 16 \%(\mathrm{w} / \mathrm{w}) \\
\kappa \text {-carrageenan and } \\
\text { hydroxypropyl ethylcellulose } \\
\text { basis) }\end{array}$ & Headspace & $25^{\circ} \mathrm{C}$ & Sun et al. (2019) \\
\hline & $\begin{array}{l}\text { Bauhinia } \\
\text { blakeana Dunn } \\
\text { flower }\end{array}$ & $\begin{array}{l}\text { Chitosan cross-linked with } \\
\text { glutaraldehyde coated with ATH extract }\end{array}$ & Extract solution & Headspace & $25^{\circ} \mathrm{C}$ & (Zhang et al., 2014) \\
\hline \multirow[t]{8}{*}{ shrimp } & Mulberry & $\begin{array}{l}\text { Polyethylene vinyl alcohol/ } \\
\text { montmorillonite film coated with a } \\
\text { solution of polyethylene vinyl alcohol } \\
\text { containing the ATH extract }\end{array}$ & $\begin{array}{l}100 \mathrm{~mL} \text { ATH solution mixed } \\
\text { with } 100 \mathrm{~mL} \text { polyethylene vinyl } \\
\text { alcohol solution }\end{array}$ & Headspace & $25^{\circ} \mathrm{C}$ & Kang et al. (2018) \\
\hline & \multirow[t]{2}{*}{ Black rice } & $\begin{array}{l}\text { Gelatine/Oxidized chitin nanocrystals } \\
\text { film }\end{array}$ & $\begin{array}{l}20,40,80 \text {, and } 100 \mathrm{mg} / 100 \mathrm{~mL} \\
\text { filmogenic solution }\end{array}$ & Headspace & $25^{\circ} \mathrm{C}$ & Ge et al. (2019) \\
\hline & & Chitosan/oxidized chitin nanocrystals & $\begin{array}{l}1 \%, 3 \% \text { and } 5 \%(w / w \text {, chitin } \\
\text { and chitosan basis) }\end{array}$ & $\begin{array}{l}\text { Direct } \\
\text { contact }\end{array}$ & $25^{\circ} \mathrm{C}$ & (Wu, Tsai, et al., 2020) \\
\hline & $\begin{array}{l}\text { Echium } \\
\text { amoenum } \\
\text { flowers }\end{array}$ & $\begin{array}{l}\text { Bacterial cellulose coated with ATH } \\
\text { extract solution }\end{array}$ & 1:1 dilution of extract solution & Headspace & $4^{\circ} \mathrm{C}$ & $\begin{array}{l}\text { Mohammadalinejhad } \\
\text { et al. (2020) }\end{array}$ \\
\hline & Jambolan fruit & Chitosan/PVA film & $\begin{array}{l}0.3 \mathrm{~g} \text { of } \mathrm{ATH} / 100 \mathrm{~g} \\
\text { macromolecules }\end{array}$ & Headspace & $-20,4$ and $20^{\circ} \mathrm{C}$ & Merz et al. (2020) \\
\hline & $\begin{array}{l}\text { Red cabbage } \\
\text { and purple } \\
\text { sweet potato }\end{array}$ & Corn starch/PVA film & $\begin{array}{l}0.25,0.5 \text { and } 1 \%(\mathrm{w} / \mathrm{v} \\
\text { filmogenic solution) }\end{array}$ & Headspace & $25^{\circ} \mathrm{C}$ & (Zhang et al., 2020) \\
\hline & Rose petals & PVA/okra mucilage polysaccharide film & $\begin{array}{l}25 \mathrm{~mL} / 100 \mathrm{~mL} \text { filmogenic } \\
\text { solution }\end{array}$ & Headspace & $25^{\circ} \mathrm{C}$ & Kang et al. (2020) \\
\hline & $\begin{array}{l}\text { Lycium } \\
\text { ruthenicum } \\
\text { Murr fruit }\end{array}$ & $\kappa$-carrageenan film & $\begin{array}{l}1.5,2.5,3.5 \text { and } 4.5 \%(\mathrm{w} / \mathrm{w}, \\
\kappa \text {-carrageenan basis })\end{array}$ & $\begin{array}{l}\text { Direct } \\
\text { contact }\end{array}$ & $25^{\circ} \mathrm{C}$ & Liu et al. (2019) \\
\hline \multirow[t]{6}{*}{ fish } & Black rice & Chitosan/oxidized chitin nanocrystals & $\begin{array}{l}1 \%, 3 \% \text { and } 5 \%(w / w \text {, chitin } \\
\text { and chitosan basis) }\end{array}$ & $\begin{array}{l}\text { Direct } \\
\text { contact }\end{array}$ & $25^{\circ} \mathrm{C}$ & (Wu et al., 2019) \\
\hline & $\begin{array}{l}\text { Purple sweet } \\
\text { potatoes/ } \\
\text { curcumin }\end{array}$ & Starch/PVA film & $4 \%(\mathrm{v} / \mathrm{v})$ filmogenic solution & Headspace & $4^{\circ} \mathrm{C}$ & $\begin{array}{l}\text { (Chen, Zhang, Bhandari, } \\
\text { \& Yang, 2020) }\end{array}$ \\
\hline & $\begin{array}{l}\text { Purple sweet } \\
\text { potato }\end{array}$ & $\begin{array}{l}\text { Carboxymethylcellulose/starch film } \\
\text { cross-linked with trimetaphospate }\end{array}$ & $\begin{array}{l}0.1,0.3,0.5,0.7 \text {, and } 0.9 \mathrm{~g} / 100 \\
\mathrm{~g} \text { filmogenic solution }\end{array}$ & Headspace & $25^{\circ} \mathrm{C}$ & Jiang et al. (2020) \\
\hline & black carrot & $\begin{array}{l}\text { Bacterial cellulose nanofibers coated } \\
\text { with ATH extract solution }\end{array}$ & $\begin{array}{l}\text { Extract solution of } 6 \mathrm{mg} / \mathrm{mL} \text { of } \\
\text { total anthocyanin content }\end{array}$ & Headspace & $4{ }^{\circ} \mathrm{C}$ & Moradi et al. (2019) \\
\hline & black rice & $\begin{array}{l}\text { Gelatine/oxidized chitin nanocrystals } \\
\text { film }\end{array}$ & $\begin{array}{l}20,40,80 \text {, and } 100 \mathrm{mg} / 100 \mathrm{~mL} \\
\text { filmogenic solution }\end{array}$ & Headspace & $25^{\circ} \mathrm{C}$ & Ge et al. (2019) \\
\hline & Roselle calyx & Starch/PVA film & & Headspace & $4^{\circ} \mathrm{C}$ & $\begin{array}{l}\text { Zhai et al. (2017) } \\
\text { (continued on next page) }\end{array}$ \\
\hline
\end{tabular}


Table 1 (continued)

\begin{tabular}{|c|c|c|c|c|c|c|}
\hline $\begin{array}{l}\text { Tested } \\
\text { food }\end{array}$ & Source of ATH & Polymeric material & ATH extract concentration & $\begin{array}{l}\text { Type of } \\
\text { contact food- } \\
\text { indicator }\end{array}$ & $\begin{array}{l}\text { Storage } \\
\text { temperature }\end{array}$ & Reference \\
\hline & & & $\begin{array}{l}30,60 \text { and } 120 \mathrm{mg} \text { of ATH/100 g } \\
\text { of starch }\end{array}$ & & & \\
\hline & Mulberry & Gelatin/PVA film & $\begin{array}{l}30, \mathrm{mg} / 100 \mathrm{~mL} \text { filmogenic } \\
\text { solution }\end{array}$ & Headspace & $25^{\circ} \mathrm{C}$ & Zeng et al. (2019) \\
\hline & & PVA/chitosan nanoparticles film & $\begin{array}{l}\text { 10, } 20,30 \text { or } 40 \%(w / w, \text { PVA } \\
\text { basis) }\end{array}$ & Headspace & Room temperature & Ma et al. (2018) \\
\hline & Red cabbage & Chitosan/corn starch film & $\begin{array}{l}5 \mathrm{~mL} / 100 \mathrm{~mL} \text { of hydrogel } \\
\text { mixture }\end{array}$ & Headspace & $\begin{array}{l}\text { Refrigeration } \\
\left(4-7^{\circ} \mathrm{C}\right) \text { and room } \\
\text { temperature } \\
\left(25^{\circ} \mathrm{C}\right)\end{array}$ & Pereira et al. (2015) \\
\hline & $\begin{array}{l}\text { Vitis amurensis } \\
\text { husk }\end{array}$ & Tara gum/cellulose nanocrystals film & $10 \%(\mathrm{w} / \mathrm{w}$, tara gum basis $)$ & Headspace & Room temperature & $\begin{array}{l}\text { Ma, Ren, Gu, and Wang } \\
\text { (2017) }\end{array}$ \\
\hline \multirow[t]{2}{*}{$\begin{array}{c}\text { Chicken } \\
\text { meat }\end{array}$} & $\begin{array}{l}\text { Blueberry } \\
\text { residue }\end{array}$ & Cassava starch film & $\begin{array}{l}4 \mathrm{~g} / 100 \mathrm{~mL} \text { of filmogenic } \\
\text { solution }\end{array}$ & $\begin{array}{l}\text { Direct } \\
\text { contact and } \\
\text { headspace }\end{array}$ & $6^{\circ} \mathrm{C}$ & Luchese et al. (2018) \\
\hline & $\begin{array}{l}\text { Butterfly pea } \\
\text { flower }\end{array}$ & Sago film & $15 \% \mathrm{w} / \mathrm{v}$ of filmogenic solution & Headspace & $23^{\circ} \mathrm{C}$ & Ahmad \\
\hline $\begin{array}{r}\text { Rutab } \\
\text { fruit }\end{array}$ & Red cabbage & PVA nanofiber mat & $30 \%(\mathrm{~g} / \mathrm{g}$ PVA $)$ & $\begin{array}{l}\text { Direct } \\
\text { contact }\end{array}$ & $25^{\circ} \mathrm{C}$ & $\begin{array}{l}\text { Maftoonazad and } \\
\text { Ramaswamy (2019) }\end{array}$ \\
\hline
\end{tabular}

Table 2

Color response of some ATH-based indicators applied to food products.

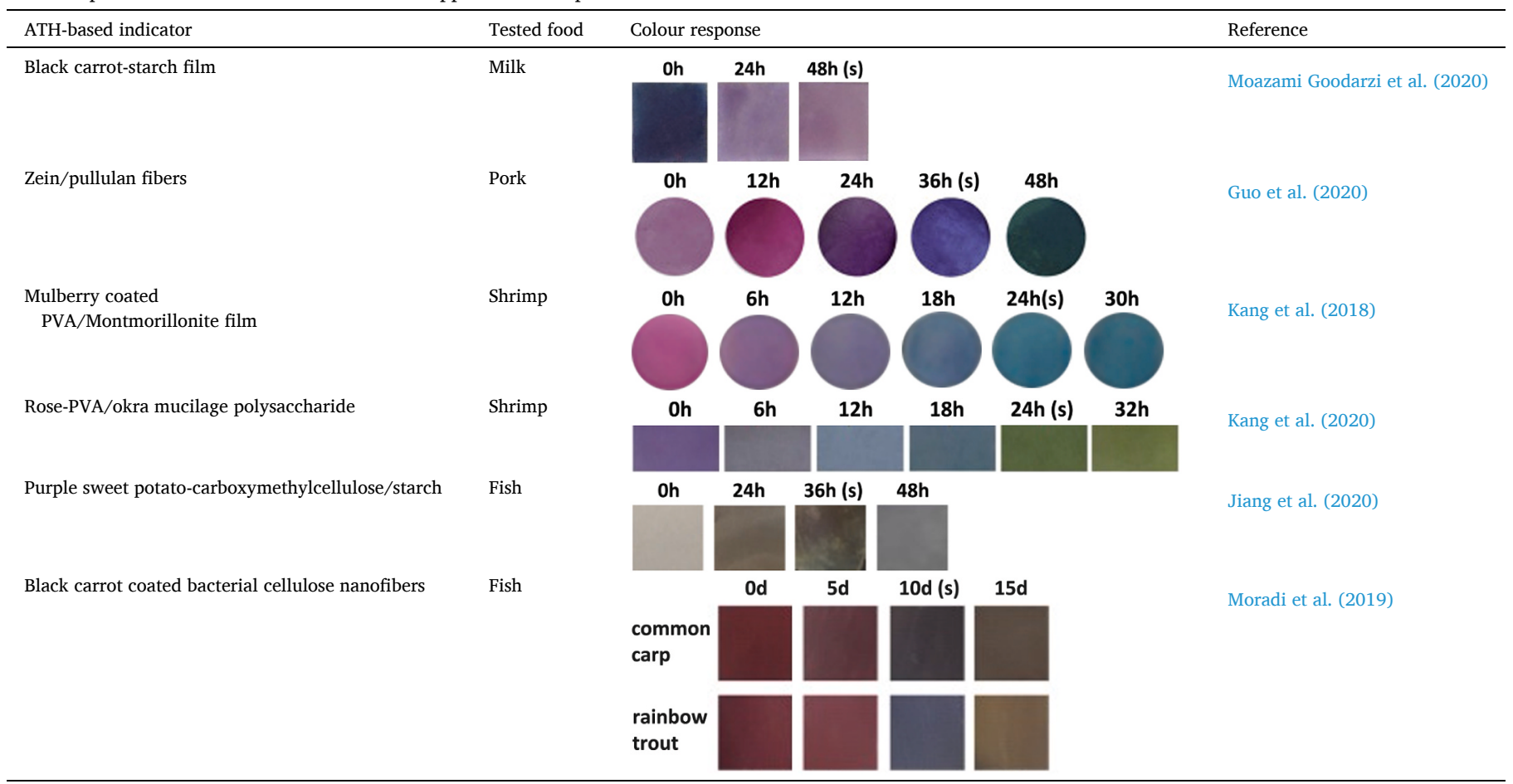

(s) spoiled.

immersed some seconds at different times of storage. This method reduces the contact times and therefore the possible associated adverse effects.

The evaluation of the practical applicability of ATH-based indicators in food spoilage has been carried out in many works at much higher temperatures $\left(20-25{ }^{\circ} \mathrm{C}\right)$ than those used commonly to store these fresh food products (Table 1). As the spoilage process in fresh products and the volatility of the chemical compounds largely depends on the storage temperature, tests at refrigeration temperatures should be performed to assure the correct performance of the $\mathrm{pH}$ indicator. In order to fulfill this goal, several works have been carried out at refrigerated temperatures using food products such as pork (Golasz et al., 2013), shrimp (Merz et al., 2020; Mohammadalinejhad et al., 2020), fish (Chen et al., 2020;
Moradi et al., 2019; Pereira et al., 2015; Zhai et al., 2017) and rutab fruit (Maftoonazad \& Ramaswamy, 2019) (Table 1) with good results.

The colour stability of a colorimetric indicator is considered as an essential parameter to give appropriate visual feedback to the consumer (Mohammadalinejhad et al., 2020). Therefore, the study of the colour evolution during storage of ATH-based indicators is compulsory for a correct applicability, even more when considering the low chemical stability of ATH. Even though only a few works addressed this topic, the results indicate that materials containing ATH change their colour during storage being the variations more noticeable at higher temperatures. Changes were detected in films containing purple sweet potato after 180 days (Chen et al., 2020), jambolan fruit after 15 days (Merz et al., 2020) and roselle after 16 days (Zhang et al., 2019). Zhai et al. 
(2017) also observed colour changes after 14 days in films stored at $4{ }^{\circ} \mathrm{C}$ containing roselle but to a lesser extent. Mohammadalinejhad et al. (2020) detected colour variations in the two first days of storage in an indicator containing $E$. amoenun, with subsequent colour maintenance in the following 4 days. In sum, More research should be conducted to study the stability of ATH-based indicators and to apply strategies for its improvement as encapsulation or copigmentation.

\section{Conclusions}

ATH-based indicators have demonstrated a great potential for monitoring freshness of several widely consumed fresh products such as seafood, meat or milk. ATH can track pH changes associated with food decay by a highly noticeable colour change that can be easily perceived by consumers. Compared to other pH-based freshness indicators, ATH have the advantage of being of natural origin, cheap and easy to incorporate in eco-friendly water-based polymers such as chitosan, cellulose o starch.

However, there are still some issues that should be overcome for a successful implementation of ATH-based indicators. Namely, the stability of ATH-based indicators should be assured during storage and distribution times, ATH losses due to migration should be limited and, the indicator water resistance should be improved. An increment of ATH stability could be achieved by copigmentation with other substances or by the encapsulation of ATH. Migration could be reduced by the incorporation of negatively charged substances in the polymer matrix that interact with ATH by covalent or non-covalent bonds. Encapsulation might be also used to control or reduce ATH release from the polymer. Besides, food trials should be extended to ensure the correct performance of ATH-based indicators considering that meat and fish products can vary their $\mathrm{pH}$ due to different factors such as breed, feeding, slaughter conditions or further processing. At the industrial level, more research is needed to scale-up the production of ATH-based indicators and to develop technically and economically feasible methods to include them in the common packaging used in food. Regarding this topic, it could be interesting to evaluate the behaviour of these indicators under real storage conditions such as modified atmosphere, refrigerated storage, changes in temperature during storage and distribution, among others.

\section{Author contributions}

$\mathrm{RB}$ is responsible for the conceptualization and the writing of the original draft FS and $\mathrm{CN}$ are responsible for the review and editing of the manuscript.

\section{Acknowledgements}

This research was funded by the Spanish Ministry of Science, Innovation and Universities through the project RTI 2018-097805-B-I00 and by the OTRI project $2016 / 0580$. The authors also acknowledge the funding provided by Aragon Government and European Social Funds to the GUIA 53-T20 group.

\section{Appendix A. Supplementary data}

Supplementary data to this article can be found online at https://doi. org/10.1016/j.tifs.2021.02.042.

\section{References}

Ahmad, S. R., Gokulakrishnan, P., Giriprasad, R., \& Yatoo, M. A. (2015). Fruit-based natural antioxidants in meat and meat products: A review. Critical Reviews in Food Science and Nutrition, 55(11), 1503-1513. https://doi.org/10.1080/ 10408398.2012.701674

Alizadeh-Sani, M., Mohammadian, E., Rhim, J. W., \& Jafari, S. M. (2020). pH-sensitive (halochromic) smart packaging films based on natural food colorants for the monitoring of food quality and safety. Trends in Food Science \& Technology, 105, 93-144. https://doi.org/10.1016/j.tifs.2020.08.014

Andretta, R., Luchese, C. L., Tessaro, I. C., \& Spada, J. C. (2019). Development and characterization of $\mathrm{pH}$-indicator films based on cassava starch and blueberry residue by thermocompression. Food Hydrocolloids, 93, 317-324. https://doi.org/10.1016/j. foodhyd.2019.02.019

Balbinot-Alfaro, E., Craveiro, D. V., Lima, K. O., Costa, H. L. G., Lopes, D. R., \& Prentice, C. (2019). Intelligent packaging with $\mathrm{pH}$ indicator potential. Food Engineering Reviews, 11(4), 235-244. https://doi.org/10.1007/s12393-019-09198-9

Becerril, R., Nerín, C., \& Silva, F. (2020). Encapsulation systems for antimicrobial food packaging components: An update. Molecules, 25(5), 1134-1174. https://doi.org/ 10.3390/molecules25051134

Bhargava, N., Sharanagat, V. S., Mor, R. S., \& Kumar, K. (2020). Active and intelligent biodegradable packaging films using food and food waste-derived bioactive compounds: A review. Trends in Food Science \& Technology, 105, 385-401. https:// doi.org/10.1016/j.tifs.2020.09.015

Borzi, F., Torrieri, E., Wrona, M., \& Nerín, C. (2019). Polyamide modified with green tea extract for fresh minced meat active packaging applications. Food Chemistry, 300, 125242. https://doi.org/10.1016/j.foodchem.2019.125242

Castañeda-Ovando, A., Pacheco-Hernández, M. de L., Páez-Hernández, M. E., Rodríguez, J. A., \& Galán-Vidal, C. A. (2009). Chemical studies of anthocyanins: A review. Food Chemistry, 113(4), 859-871. https://doi.org/10.1016/j. foodchem.2008.09.001

Cavalcanti, R. N., Santos, D. T., \& Meireles, M. A. A. (2011). Non-thermal stabilization mechanisms of anthocyanins in model and food systems-An overview. Food Research International, 44(2), 499-509. https://doi.org/10.1016/j.foodres.2010.12.007

Chen, X., \& Gu, Z. (2013). Absorption-type optical pH sensitive film based on immobilized purple cabbage pigment. Sensors and Actuators B: Chemical, 178, 207-211. https://doi.org/10.1016/j.snb.2012.12.094

Chen, H. zhi, Zhang, M., Bhandari, B., \& Yang, C. hui (2020). Novel pH-sensitive films containing curcumin and anthocyanins to monitor fish freshness. Food Hydrocolloids, 100, 105438. https://doi.org/10.1016/j.foodhyd.2019.105438

Chi, W., Cao, L., Sun, G., Meng, F., Zhang, C., Li, J., et al. (2020). Developing a highly pHsensitive к-carrageenan-based intelligent film incorporating grape skin powder via a cleaner process. Journal of Cleaner Production, 244, 118862. https://doi.org/ 10.1016/j.jclepro.2019.118862

Choi, I., Lee, J. Y., Lacroix, M., \& Han, J. (2017). Intelligent pH indicator film composed of agar/potato starch and anthocyanin extracts from purple sweet potato. Food Chemistry, 218, 122-128. https://doi.org/10.1016/j.foodchem.2016.09.050

Chung, C., Rojanasasithara, T., Mutilangi, W., \& McClements, D. J. (2015). Enhanced stability of anthocyanin-based color in model beverage systems through whey protein isolate complexation. Food Research International, 76, 761-768. https://doi. org/10.1016/j.foodres.2015.07.003

Clifford, M. N. (2000). Anthocyanins - nature, occurrence and dietary burden. Journal of the Science of Food and Agriculture, 80(7), 1063-1072. https://doi.org/10.1002/ (SICI)1097-0010(20000515)80:7<1063::AID-JSFA605>3.0.CO;2-Q

Cortez, R., Luna-Vital, D. A., Margulis, D., \& Gonzalez de Mejia, E. (2017). Natural pigments: Stabilization methods of anthocyanins for food applications. Comprehensive Reviews in Food Science and Food Safety, 16(1), 180-198. https://doi. org/10.1111/1541-4337.12244

De Moraes, J. O., Scheibe, A. S., Sereno, A., \& Laurindo, J. B. (2013). Scale-up of the production of cassava starch based films using tape-casting. Journal of Food Engineering, 119(4), 800-808. https://doi.org/10.1016/j.jfoodeng.2013.07.009

Ebrahimi Tirtashi, F., Moradi, M., Tajik, H., Forough, M., Ezati, P., \& Kuswandi, B. (2019). Cellulose/chitosan pH-responsive indicator incorporated with carrot anthocyanins for intelligent food packaging. International Journal of Biological Macromolecules, 136, 920-926. https://doi.org/10.1016/j.ijbiomac.2019.06.148

EFSA. (2013). Scientific Opinion on the re-evaluation of anthocyanins (E 163) as a food additive. EFSA Journal, 11(4), 3145-3196. https://doi.org/10.2903/j. efsa.2013.3145

Fang, Z., Zhao, Y., Warner, R. D., \& Johnson, S. K. (2017). Active and intelligent packaging in meat industry. Trends in Food Science \& Technology, 61, 60-71. https:// doi.org/10.1016/j.tifs.2017.01.002

Ge, Y., Li, Y., Bai, Y., Yuan, C., Wu, C., \& Hu, Y. (2019). Intelligent gelatin/oxidized chitin nanocrystals nanocomposite films containing black rice bran anthocyanins for fish freshness monitorings. International Journal of Biological Macromolecules, 155, 1296-1306. https://doi.org/10.1016/j.ijbiomac.2019.11.101

Gherardi, R., Becerril, R., Nerin, C., \& Bosetti, O. (2016). Development of a multilayer antimicrobial packaging material for tomato puree using an innovative technology. Lebensmittel-Wissenschaft und -Technologie- Food Science and Technology, 72. https:// doi.org/10.1016/j.lwt.2016.04.063

Golasz, L. B., Silva, J. D.a, \& Botelho Da Silva, S. (2013). Film with anthocyanins as an indicator of chilled pork deterioration. Ciencia y Tecnologia Alimentaria, 33(Supl. 1), $155-162$.

Gómez-Estaca, J., Gavara, R., Catalá, R., \& Hernández-Muñoz, P. (2016). The potential of proteins for producing food packaging materials: A review. Packaging Technology and Science, 29(4-5), 203-224. https://doi.org/10.1002/pts.2198

Di Gu, K., Wang, C. K., Hu, D. G., \& Hao, Y. J. (2019). How do anthocyanins paint our horticultural products? Scientia Horticulturae, 249, 257-262. https://doi.org/ 10.1016/j.scienta.2019.01.034

Guo, M., Wang, H., Wang, Q., Chen, M., Li, L., Li, X., et al. (2020). Intelligent doublelayer fiber mats with high colorimetric response sensitivity for food freshness monitoring and preservation. Food Hydrocolloids, 101, 105468. https://doi.org/ 10.1016/j.foodhyd.2019.105468 
Halász, K., \& Csóka, L. (2018). Black chokeberry (Aronia melanocarpa) pomace extract immobilized in chitosan for colorimetric $\mathrm{pH}$ indicator film application. Food Packaging and Shelf Life, 16, 185-193. https://doi.org/10.1016/j.fpsl.2018.03.002

Han, J. W., Ruiz-Garcia, L., Qian, J. P., \& Yang, X. T. (2018). Food packaging: A comprehensive review and future trends. Comprehensive Reviews in Food Science and Food Safety, 17(4), 860-877. https://doi.org/10.1111/1541-4337.12343

Jiang, G., Hou, X., Zeng, X., Zhang, C., Wu, H., Shen, G., ... Zhang, Z. (2020). Preparation and characterization of indicator films from carboxymethyl-cellulose/starch and purple sweet potato (Ipomoea batatas (L.) lam) anthocyanins for monitoring fish freshness. International Journal of Biological Macromolecules, 143, 359-372. https:// doi.org/10.1016/j.ijbiomac.2019.12.024

Kalpana, S., Priyadarshini, S. R., Maria Leena, M., Moses, J. A., \& Anandharamakrishnan, C. (2019). Intelligent packaging: Trends and applications in food systems. Trends in Food Science \& Technology, 93, 145-157. https://doi.org/ 10.1016/j.tifs.2019.09.008

Kang, S., Wang, H., Guo, M., Zhang, L., Chen, M., Jiang, S., ... Jiang, S. (2018). Ethylenevinyl alcohol copolymer-montmorillonite multilayer barrier film coated with mulberry anthocyanin for freshness monitoring. Journal of Agricultural and Food Chemistry, 66(50), 13268-13276. https://doi.org/10.1021/acs.jafc.8b05189

Kang, S., Wang, H., Xia, L., Chen, M., Li, L., Cheng, J., ... Jiang, S. (2020). Colorimetric film based on polyvinyl alcohol/okra mucilage polysaccharide incorporated with rose anthocyanins for shrimp freshness monitoring. Carbohydrate Polymers, 229, 115402. https://doi.org/10.1016/j.carbpol.2019.115402

Khoo, H. E., Azlan, A., Tang, S. T., \& Lim, S. M. (2017). Anthocyanidins and anthocyanins: Colored pigments as food, pharmaceutical ingredients, and the potential health benefits. Food \& Nutrition Research, 61, 1361779. https://doi.org/ 10.1080/16546628.2017.1361779

Koh, J., Xu, Z., \& Wicker, L. (2020). Binding kinetics of blueberry pectin-anthocyanins and stabilization by non-covalent interactions. Food Hydrocolloids, 99, 105354. https://doi.org/10.1016/j.foodhyd.2019.105354

Koosha, M., \& Hamedi, S. (2019). Intelligent Chitosan/PVA nanocomposite films containing black carrot anthocyanin and bentonite nanoclays with improved mechanical, thermal and antibacterial properties. Progress in Organic Coatings, 127, 338-347. https://doi.org/10.1016/j.porgcoat.2018.11.028

Kurek, M., Garofulić, I. E., Bakić, M. T., Ščetar, M., Uzelac, V. D., \& Galić, K. (2018). Development and evaluation of a novel antioxidant and $\mathrm{pH}$ indicator film based on chitosan and food waste sources of antioxidants. Food Hydrocolloids, 84, 238-246. https://doi.org/10.1016/j.foodhyd.2018.05.050

Kuswandi, B. (2017). Freshness sensors for food packaging. Reference module in food science. https://doi.org/10.1016/b978-0-08-100596-5.21876-3

Kuswandi, B., Asih, N. P. N., Pratoko, D. K., Kristiningrum, N., \& Moradi, M. (2020). Edible $\mathrm{pH}$ sensor based on immobilized red cabbage anthocyanins into bacterial cellulose membrane for intelligent food packaging. Packaging Technology and Science, 1-12. https://doi.org/10.1002/pts.2507

Liang, T., Sun, G., Cao, L., Li, J., \& Wang, L. (2019). A pH and NH3 sensing intelligent film based on Artemisia sphaerocephala Krasch. gum and red cabbage anthocyanins anchored by carboxymethyl cellulose sodium added as a host complex. Food Hydrocolloids, 87, 858-868. https://doi.org/10.1016/j.foodhyd.2018.08.028

Liu, J., Wang, H., Guo, M., Li, L., Chen, M., Jiang, S., ... Jiang, S. (2019). Extract from Lycium ruthenicum Murr. Incorporating $\kappa$-carrageenan colorimetric film with a wide pH-sensing range for food freshness monitoring. Food Hydrocolloids, 94, 1-10. https://doi.org/10.1016/j.foodhyd.2019.03.008

Li, S., Wu, B., Fu, W., \& Reddivari, L. (2019). The anti-inflammatory effects of dietary anthocyanins against ulcerative colitis. International Journal of Molecular Sciences, 20 https://doi.org/10.3390/ijms20102588

Li, A., Xiao, R., He, S., An, X., He, Y., Wang, C., ... He, J. (2019). Research advances of purple sweet potato anthocyanins: Extraction, identification, stability, bioactivity, application, and biotransformation. Molecules, 24(21), 3816. https://doi.org/ 10.3390/molecules24213816

Lorenzo, J. M., Pateiro, M., Domínguez, R., Barba, F. J., Putnik, P., Kovačević, D. B., Franco, D. (2018). Berries extracts as natural antioxidants in meat products: A review. Food Research International, 106, 1095-1104. https://doi.org/10.1016/j. foodres.2017.12.005

Luchese, C. L., Abdalla, V. F., Spada, J. C., \& Tessaro, I. C. (2018). Evaluation of blueberry residue incorporated cassava starch film as $\mathrm{pH}$ indicator in different simulants and foodstuffs. Food Hydrocolloids, 82, 209-218. https://doi.org/10.1016/ j.foodhyd.2018.04.010

Luchese, C. L., Sperotto, N., Spada, J. C., \& Tessaro, I. C. (2017). Effect of blueberry agroindustrial waste addition to corn starch-based films for the production of a $\mathrm{pH}$ indicator film. International Journal of Biological Macromolecules, 104, 11-18. https:// doi.org/10.1016/j.ijbiomac.2017.05.149

Maciel, V. B. V., Yoshida, C. M. P., \& Franco, T. T. (2015). Chitosan/pectin polyelectrolyte complex as a $\mathrm{pH}$ indicator. Carbohydrate Polymers, 132, 537-545. https://doi.org/10.1016/j.carbpol.2015.06.047

Maftoonazad, N., \& Ramaswamy, H. (2019). Design and testing of an electrospun nanofiber mat as a $\mathrm{pH}$ biosensor and monitor the $\mathrm{pH}$ associated quality in fresh date fruit (Rutab). Polymer Testing, 75, 76-84. https://doi.org/10.1016/j. polymertesting.2019.01.011

Ma, Q., Liang, T., Cao, L., \& Wang, L. (2018). Intelligent poly (vinyl alcohol)-chitosan nanoparticles-mulberry extracts films capable of monitoring $\mathrm{pH}$ variations. International Journal of Biological Macromolecules, 108, 576-584. https://doi.org/ 10.1016/j.ijbiomac.2017.12.049

Ma, Q., Ren, Y., Gu, Z., \& Wang, L. (2017). Developing an intelligent film containing Vitis amurensis husk extracts: The effects of $\mathrm{pH}$ value of the film-forming solution. Journal of Cleaner Production, 166, 851-859. https://doi.org/10.1016/j.jclepro.2017.08.099
Ma, Q., \& Wang, L. (2016). Preparation of a visual pH-sensing film based on tara gum incorporating cellulose and extracts from grape skins. Sensors and Actuators $B$ Chemical, 235, 401-407. https://doi.org/10.1016/j.snb.2016.05.107

Merz, B., Capello, C., Leandro, G. C., Moritz, D. E., Monteiro, A. R., \& Valencia, G. A. (2020). A novel colorimetric indicator film based on chitosan, polyvinyl alcohol and anthocyanins from jambolan (Syzygium cumini) fruit for monitoring shrimp freshness. International Journal of Biological Macromolecules, 153, 625-632. https:// doi.org/10.1016/j.ijbiomac.2020.03.048

Moazami Goodarzi, M., Moradi, M., Tajik, H., Forough, M., Ezati, P., \& Kuswandi, B. (2020). Development of an easy-to-use colorimetric $\mathrm{pH}$ label with starch and carrot anthocyanins for milk shelf life assessment. International Journal of Biological Macromolecules, 153, 240-247. https://doi.org/10.1016/j.ijbiomac.2020.03.014

Mohamed, S. A. A., El-Sakhawy, M., \& El-Sakhawy, M. A. M. (2020). Polysaccharides, protein and lipid -based natural edible films in food packaging: A review. Carbohydrate Polymers, 238, 116178. https://doi.org/10.1016/j. carbpol.2020.116178

Mohammadalinejhad, S., Almasi, H., \& Moradi, M. (2020). Immobilization of Echium amoenum anthocyanins into bacterial cellulose film: A novel colorimetric $\mathrm{pH}$ indicator for freshness/spoilage monitoring of shrimp. Food Control, 113. https:// doi.org/10.1016/j.foodcont.2020.107169

Moradi, M., Tajik, H., Almasi, H., Forough, M., \& Ezati, P. (2019). A novel pH-sensing indicator based on bacterial cellulose nanofibers and black carrot anthocyanins for monitoring fish freshness. Carbohydrate Polymers, 222, 115030. https://doi.org/ 10.1016/j.carbpol.2019.115030

Müller, P., \& Schmid, M. (2019). Intelligent packaging in the food sector: A brief overview. Foods, 8(1), 16. https://doi.org/10.3390/foods8010016

Mustafa, P., Niazi, M. B. K., Jahan, Z., Samin, G., Hussain, A., Ahmed, T., et al. (2020). PVA/starch/propolis/anthocyanins rosemary extract composite films as active and intelligent food packaging materials. Journal of Food Safety, 40(1), Article e12725. https://doi.org/10.1111/jfs.12725

Nerin, C., Becerril, R., Manso, S., \& Silva, F. (2016). Ethyl lauroyl arginate (LAE): Antimicrobial activity and applications in food systems. Antimicrobial food packaging. https://doi.org/10.1016/B978-0-12-800723-5.00023-1

Pereira, V. A., de Arruda, I. N. Q., \& Stefani, R. (2015). Active chitosan/PVA films with anthocyanins from Brassica oleraceae (Red Cabbage) as Time-Temperature Indicators for application in intelligent food packaging. Food Hydrocolloids, 43, 180-188. https://doi.org/10.1016/j.foodhyd.2014.05.014

Pourjavaher, S., Almasi, H., Meshkini, S., Pirsa, S., \& Parandi, E. (2017). Development of a colorimetric $\mathrm{pH}$ indicator based on bacterial cellulose nanofibers and red cabbage (Brassica oleraceae) extract. Carbohydrate Polymers, 156, 193-201. https://doi.org/ 10.1016/j.carbpol.2016.09.027

Poyatos-Racionero, E., Ros-Lis, J. V., Vivancos, J. L., \& Martínez-Máñez, R. (2018). Recent advances on intelligent packaging as tools to reduce food waste. Journal of Cleaner Production, 172, 3398-3409. https://doi.org/10.1016/j.jclepro.2017.11.075

Prietto, L., Pinto, V. Z., El Halal, S. L. M., de Morais, M. G., Costa, J. A. V., Lim, L.-T., .. Zavareze, E. da R. (2018). Ultrafine fibers of zein and anthocyanins as natural $\mathrm{pH}$ indicator. Journal of the Science of Food and Agriculture, 98(7), 2735-2741. https:// doi.org/10.1002/jsfa.8769

Qin, Y., Liu, Y., Yong, H., Liu, J., Zhang, X., \& Liu, J. (2019). Preparation and characterization of active and intelligent packaging films based on cassava starch and anthocyanins from Lycium ruthenicum Murr. International Journal of Biological Macromolecules, 134, 80-90. https://doi.org/10.1016/j.ijbiomac.2019.05.029

Rawdkuen, S., Faseha, A., Benjakul, S., \& Kaewprachu, P. (2020). Application of anthocyanin as a color indicator in gelatin films. Food Bioscience, 36, 100603. https://doi.org/10.1016/j.fbio.2020.100603

Rodriguez-Amaya, D. B. (2019). Update on natural food pigments - a mini-review on carotenoids, anthocyanins, and betalains. Food Research International, 124, 200-205. https://doi.org/10.1016/j.foodres.2018.05.028

Roy, S., \& Rhim, J.-W. (2020). Anthocyanin food colorant and its application in pHresponsive color change indicator films. Critical Reviews in Food Science and Nutrition, 1-29. https://doi.org/10.1080/10408398.2020.1776211

Silva-Pereira, M. C., Teixeira, J. A., Pereira-Júnior, V. A., \& Stefani, R. (2015). Chitosan/ corn starch blend films with extract from Brassica oleraceae (red cabbage) as a visual indicator of fish deterioration. Lebensmittel-Wissenschaft und -Technologie- Food Science and Technology, 61(1), 258-262. https://doi.org/10.1016/j.lwt.2014.11.041

Silva, S., Costa, E. M., Calhau, C., Morais, R. M., \& Pintado, M. E. (2017). Anthocyanin extraction from plant tissues: A review. Critical Reviews in Food Science and Nutrition, 57(14), 3072-3083. https://doi.org/10.1080/10408398.2015.1087963

Silva, F., Domingues, F. C., \& Nerín, C. (2018). Control microbial growth on fresh chicken meat using pinosylvin inclusion complexes based packaging absorbent pads. Lebensmittel-Wissenschaft und -Technologie- Food Science and Technology, 89, 148-154. https://doi.org/10.1016/j.lwt.2017.10.043

Silva, C. K. da, Mastrantonio, D. J. da S., Costa, J. A. V., \& de Morais, M. G. (2019). Innovative $\mathrm{pH}$ sensors developed from ultrafine fibers containing açaí (Euterpe oleracea) extract. Food Chemistry, 294, 397-404. https://doi.org/10.1016/j. foodchem.2019.05.059

Smeriglio, A., Barreca, D., Bellocco, E., \& Trombetta, D. (2016). Chemistry, pharmacology and health benefits of anthocyanins. Phytotheraphy Reseach, 30, 1265-1286. https://doi.org/10.1002/ptr.5642

Strauch, R. C., Mengist, M. F., Pan, K., Yousef, G. G., Iorizzo, M., Brown, A. F., et al. (2019). Variation in anthocyanin profiles of 27 genotypes of red cabbage over two growing seasons. Food Chemistry, 301, 125289. https://doi.org/10.1016/j. foodchem.2019.125289

Sun, G., Chi, W., Zhang, C., Xu, S., Li, J., \& Wang, L. (2019). Developing a green film with pH-sensitivity and antioxidant activity based on $к$-carrageenan and hydroxypropyl 
methylcellulose incorporating Prunus maackii juice. Food Hydrocolloids, 94, 345-353. https://doi.org/10.1016/j.foodhyd.2019.03.039

Tarone, A. G., Cazarin, C. B. B., \& Marostica Junior, M. R. (2020). Anthocyanins: New techniques and challenges in microencapsulation. Food Research International, 133, 109092. https://doi.org/10.1016/j.foodres.2020.109092

Tsuda, T. (2012). Dietary anthocyanin-rich plants: Biochemical basis and recent progress in health benefits studies. Molecular Nutrition \& Food Research, 56, 159-170. https:// doi.org/10.1002/mnfr.201100526

Uranga, J., Etxabide, A., Guerrero, P., \& de la Caba, K. (2018). Development of active fish gelatin films with anthocyanins by compression molding. Food Hydrocolloids, 84, 313-320. https://doi.org/10.1016/j.foodhyd.2018.06.018

Vanderroost, M., Ragaert, P., Devlieghere, F., \& De Meulenaer, B. (2014). Intelligent food packaging: The next generation. Trends in Food Science \& Technology, 39(1), 47-62. https://doi.org/10.1016/j.tifs.2014.06.009

Vo, Dang, \& Chen. (2019). Synthesis of intelligent $\mathrm{pH}$ indicative films from chitosan/poly (vinyl alcohol)/anthocyanin extracted from red cabbage. Polymers, 11(7), 1088. https://doi.org/10.3390/polym11071088

Wallace, T. C., \& Giusti, M. M. (2015). Anthocyanins. Advances in Nutrition, 6(5), 619-622. https://doi.org/10.3945/an.115.009233

Wang, S., Xia, P., Wang, S., Liang, J., Sun, Y., Yue, P., et al. (2019a). Packaging films formulated with gelatin and anthocyanins nanocomplexes: Physical properties, antioxidant activity and its application for olive oil protection. Food Hydrocolloids, 96, 617-624. https://doi.org/10.1016/j.foodhyd.2019.06.004

Wang, X., Yong, H., Gao, L., Li, L., Jin, M., \& Liu, J. (2019b). Preparation and characterization of antioxidant and $\mathrm{pH}$-sensitive films based on chitosan and black soybean seed coat extract. Food Hydrocolloids, 89, 56-66. https://doi.org/10.1016/j. foodhyd.2018.10.019

Wei, Y. C., Cheng, C. H., Ho, Y. C., Tsai, M. L., \& Mi, F. L. (2017). Active gellan gum/ purple sweet potato composite films capable of monitoring $\mathrm{pH}$ variations. Food Hydrocolloids, 69, 491-502. https://doi.org/10.1016/j.foodhyd.2017.03.010

Wrona, M., Blasco, S., Becerril, R., Nerin, C., Sales, E., \& Asensio, E. (2019). Antioxidant and antimicrobial markers by UPLC $®$-ESI-Q-TOF-MSE of a new multilayer active packaging based on Arctostaphylos uva-ursi. Talanta, 196. https://doi.org/10.1016/ j.talanta.2018.12.057

Wu, C., Li, Y., Sun, J., Lu, Y., Tong, C., Wang, L., et al. (2020). Novel konjac glucomannan films with oxidized chitin nanocrystals immobilized red cabbage anthocyanins for intelligent food packaging. Food Hydrocolloids, 98, 105245. https://doi.org/ 10.1016/j.foodhyd.2019.105245

Wu, C., Sun, J., Zheng, P., Kang, X., Chen, M., Li, Y., ... Pang, J. (2019). Preparation of an intelligent film based on chitosan/oxidized chitin nanocrystals incorporating black rice bran anthocyanins for seafood spoilage monitoring. Carbohydrate Polymers, 222, 115006. https://doi.org/10.1016/j.carbpol.2019.115006

Wu, L.-T., Tsai, I.-L., Ho, Y.-C., Hang, Y.-H., Lin, C., Tsai, M.-L., ... Pang, J. (2020). Active and intelligent gellan gum-based packaging films for controlling anthocyanins release and monitoring food freshness. Carbohydrate Polymers, 254, 117410. https:// doi.org/10.1016/j.carbpol.2020.117410
Wu, Y.-M., Wang, Z.-W., Hu, C.-Y., \& Nerín, C. (2018). Influence of factors on release of antimicrobials from antimicrobial packaging materials. Critical Reviews in Food Science and Nutrition, 58(7), 1108-1121. https://doi.org/10.1080/ 10408398.2016.1241215

Xu, X. J., Fang, S., Li, Y. H., Zhang, F., Shao, Z. P., Zeng, Y. T., ... Meng, Y. C. (2019) Effects of low acyl and high acyl gellan gum on the thermal stability of purple sweet potato anthocyanins in the presence of ascorbic acid. Food Hydrocolloids, 86, 116-123. https://doi.org/10.1016/j.foodhyd.2018.03.007

Yam, K. L., Takhistov, P. T., \& Miltz, J. (2005). Intelligent packaging: Concepts and applications. Journal of Food Science, 70(1), R1-R10. https://doi.org/10.1111/ j.1365-2621.2005.tb09052.x

Yong, H., Wang, X., Bai, R., Miao, Z., Zhang, X., \& Liu, J. (2019). Development of antioxidant and intelligent $\mathrm{pH}$-sensing packaging films by incorporating purplefleshed sweet potato extract into chitosan matrix. Food Hydrocolloids, 90, 216-224. https://doi.org/10.1016/j.foodhyd.2018.12.015

Yong, H., Wang, X., Zhang, X., Liu, Y., Qin, Y., \& Liu, J. (2019). Effects of anthocyaninrich purple and black eggplant extracts on the physical, antioxidant and $\mathrm{pH}$-sensitive properties of chitosan film. Food Hydrocolloids, 94, 93-104. https://doi.org/ 10.1016/j.foodhyd.2019.03.012

Yoshida, C. M. P., Maciel, V. B. V., Mendonça, M. E. D., \& Franco, T. T. (2014). Chitosan biobased and intelligent films: Monitoring $\mathrm{pH}$ variations. Lebensmittel-Wissenschaft und -Technologie- Food Science and Technology, 55(1), 83-89. https://doi.org/ 10.1016/j.lwt.2013.09.015

Zeng, P., Chen, X., Qin, Y. R., Zhang, Y. H., Wang, X. P., Wang, J. Y., ... Zhang, Y. S. (2019). Preparation and characterization of a novel colorimetric indicator film based on gelatin/polyvinyl alcohol incorporating mulberry anthocyanin extracts for monitoring fish freshness. Food Research International, 126, 108604. https://doi.org/ 10.1016/j.foodres.2019.108604

Zhai, X., Shi, J., Zou, X., Wang, S., Jiang, C., Zhang, J., ... Holmes, M. (2017). Novel colorimetric films based on starch/polyvinyl alcohol incorporated with roselle anthocyanins for fish freshness monitoring. Food Hydrocolloids, 69, 308-317. https://doi.org/10.1016/j.foodhyd.2017.02.014

Zhang, K., Huang, T. S., Yan, H., Hu, X., \& Ren, T. (2020). Novel pH-sensitive films based on starch/polyvinyl alcohol and food anthocyanins as a visual indicator of shrimp deterioration. International Journal of Biological Macromolecules, 145, 768-776. https://doi.org/10.1016/j.ijbiomac.2019.12.159

Zhang, X., Lu, S., \& Chen, X. (2014). A visual pH sensing film using natural dyes from Bauhinia blakeana Dunn. Sensors and Actuators B: Chemical, 198, 268-273. https:// doi.org/10.1016/j.snb.2014.02.094

Zhang, J., Zou, X., Zhai, X., Huang, X. W., Jiang, C., \& Holmes, M. (2019). Preparation of an intelligent $\mathrm{pH}$ film based on biodegradable polymers and roselle anthocyanins for monitoring pork freshness. Food Chemistry, 272, 306-312. https://doi.org/10.1016/ j.foodchem.2018.08.041

Zhao, C. L., Yu, Y. Q., Chen, Z. J., Wen, G. S., Wei, F. G., Zheng, Q., ... Xiao, X. L. (2017). Stability-increasing effects of anthocyanin glycosyl acylation. Food Chemistry, 214, 119-128. https://doi.org/10.1016/j.foodchem.2016.07.073 